\title{
PERANCANGANSISTEM INFORMASI PERSEDIAAN BARANG PADA PERUSAHAAN KARYA CIPTA BUANA SENTOSA BERBASIS WEB DENGAN METODE EXTREME PROGRAMING
}

\author{
Ressa Priskila \\ Teknik Informatika-UniversitasPalangka Raya \\ Jl. H. TimangPalangka Raya, Kalimantan Tengah, Indonesia,73112 \\ ressapriskila1@gmail.com
}

\begin{abstract}
Abstrak-Peran teknologi informasi dalam dunia bisnis sangat besaruntuk meningkatkan efektivitas, produktivitas dan daya saing perusahaan. Perusahaan Karya Cipta Buana Sentosa merupakan sebuah perusahaan yang bergerak di bidang pengolahan dan pendistribusian hasil laut di Nusa Tenggara Timur. Sebagai sebuah perusahaan pendistribusi hasil laut, pengelolaan persediaanbarang adalah bagian yang sangat penting dalam bisnis proses perusahaan. Kesulitan mencari informasi mengenai stok barang dan pembuatan laporan barang masuk dan keluar menjadi masalah yang dihadapi perusahaan. Untuk mengatasi masalah tersebut dibutuhkan sistem informasi yang dapat memenuhi kebutuhan informasi perusahaan. Penelitian ini bertujuan untuk merancang sistem informasi persediaan barang berbasis web pada perusahaan Karya Cipta Buana Sentosa menggunakan metode Extreme Programming (XP). Sistem informasi ini terdiri dari 3 pengguna yaitu admin, staf gudang dan manajer. Dengan adanya sistem informasi ini, pengelolaan persediaan barang menjadi lebih efektif dan efisien, pencarian informasi persediaan/stok dan laporan juga lebih akurat dan cepat.
\end{abstract}

Keywords—Sistem informasi, metode agile,Extreme Programming, stok barang.

\section{PENDAHULUAN}

Perkembangan teknologi informasi saat ini berdampak sangat besar dalam segala aspek kehidupan, termasuk dalam dunia bisnis. Teknologi informasi sudah menjadi kebutuhan bagi dunia bisnis untuk meningkatkan efektivitas, produktivitas dan daya saing[1]. Dengan adanya teknologi informasi aliran informasi menjadi lebih cepat, akurat dan dapat dipercaya [2].

Perusahaan Karya Cipta Buana Sentosa merupakan perusahaan pengolahan dan pendistribusian hasil laut di Nusa Tenggara Timur. Perusahaan ini memproduksi 150 - 300 ton ikan beku per bulanyang dijual di dalam maupun di luar daerah Nusa Tenggara Timur bahkan sampaike luar negeri. Sebagai sebuah perusahaan pengolahan dan pendistribusian ikan, pengelolaanpersediaan barang (ikan) sangat penting dalam bisnis proses perusahaan. Pengelolaan persediaan barang yang baik sangat diperlukan untuk meningkatkan kinerja perusahaan [3].Evaluasi terhadap bisnis proses juga perlu dilakukan untuk mempertahankan pelanggan[4]

Dalam prakteknya perusahaan ini masih menggunakan program Microsoft Excel dalam pencatatan persediaan barang seperti data barang masuk dan keluar, ketersediaan barang di gudang dan juga dalam penyajian laporan. Masalahnya adalah ketika membutuhkan informasi ketersediaan (stok) dan laporan harus membuka file atau tabel satu persatu. Hal ini dirasa tidak efektif dan efisien.Karena itu dibutuhkan suatu sistem informasi yang dapat menunjang kebutuhan informasi perusahaan yang lebih efektif dan efisien dalam pengelolaan persediaan. Sistem informasi tersebut adalah sistem informasi persediaan barang.

Pengembangan sebuah perangkat lunak/sistem informasi membutuhkan tahapan-tahapan yang tepat untuk memenuhi kebutuhan pengguna[5]. Penelitian ini menggunakan pendekatan Agile Software Development yaitu Extreme programming $(X P)$. Metode Extreme Programming(XP)dipilih karena pembangunan sistem yang lebih cepat dan sangat fleksibel denganperubahan yang terjadi pada proses pembangunan perangkat lunak. Artinya selama pembangunan sistem berjalan klien diberikan kesempatan untuk menambahkan atau merubah proses bisnis, sehingga perangkat lunak yang dikembangkan dapat berhasil dan sesuai dengan keinginan pengguna[6].

Tujuan penelitian ini adalah merancang sebuah sistem informasi persediaan (stok) barang berbasis web menggunakan metode ExtremeProgramming(XP)untuk mengatasi permasalahan pengelolaanpersediaan barang yang ada di perusahaan. Diharapkan dengan adanya sistem informasi ini, pengelolaan persediaan barang menjadi lebih efektif dan efisien,pencarian informasi persediaan/stok dan laporan juga lebih akurat dan cepat.

\section{LANDASAN TEORI}

Agile Software Developmentadalah sekumpulan metodologi pengembangan perangkat lunak yang 
mempunyai prinsip yang sama serta membutuhkan adaptasi cepat dari developerterhadap perubahan selama proses pembangunan sistem [7]. Dalam metode agile terdapat prinsip utama (agile manifesto), yaitu individu dan interaksi lebih penting daripada prosesnya, perangkat lunak yang berjalan dengan baik lebih penting daripada dokumentasi perangkat lunak Page | 95 yang lengkap, kolaborasi antara developer/pengembang dan klien lebih penting daripada kontrak, dan merespons perubahan lebih penting daripada mematuhi rencana [8].

Menurut Agile Alliance sebuah tim akan sukses menerapkan metode agile,apabila memperhatikan 12 prinsip agile yang dijabarkan dari keempat prinsip utama, yaitu sebagai berikut:

- Memuaskan klien dengan menghasilkan produk perangkat lunak yang baik secara cepat dan rutin adalah prioritas utama.

- Selalu siap menerima perubahan sesuai kebutuhan.

- Menghasilkan dan menyerahkan produk perangkat lunak dalam jangka waktu pendek yaitu hitungan minggu atau bulan.

- Klien dan pengembang harus bekerja bersama selama pengembangan proyek perangkat lunak

- Mengembangkan proyek dilingkungan yang memiliki suasana yang motivatif dengan memberikan dukungan yang dibutuhkan setiap anggota tim pengembang dan mempercayai mereka untuk dapat menyelesaikan pekerjaan dengan baik.

- Berkomunikasi secara langsung merupakan cara bertukar informasi yang paling efektif dan efisien

- Ukuran utama kemajuan suatu tim adalah perangka lunak yang berfungsi dengan baik

- Dukungan yang stabil dan terus menerus dari sponsor, pengembang dan pengguna dibutuhkan dalam pembangunan perangkat lunak

- Untuk meningkatkan agility perhatian pada detail teknis dan desain dibutuhkan

- Kesederhanaan merupakan hal yang sangat utama

- Kebutuhan, desain dan arsitektur perangkat lunak yang baik akan datang dari tim yang terorganisir dengan baik

- Evaluasi dilakukan secara periodik untuk menyesuaikan cara kerja mereka supaya pengembangan proyek dapat lebih efektif.

Kelebihan metode agile adalah kepuasan klien yang meningkat, sistem dibangun dengan lebih cepat, menurunkanrisiko kegagalan pengimplementasian perangkat lunak dari aspek pengguna dan apabila terjadi kegagalan pada saat pengembangan sistem kerugian materi relatif kecil. Salah satu model dari metode pengembangan agileadalah Extreme Programming (XP)yang akan digunakan dalam penelitian ini.
Extreme programming $(X P)$ adalah model paling populer dan banyak digunakan untuk mengembangkan perangkat lunak dengan kualitas tinggi dalam metode pengembangan agile.

Ekstrem programming $(X P)$ berfokus pada peningkatan kualitas perangkat lunak dan pada respons terhadap perubahan kebutuhan.[5]Pada metode agile sistem dibangun dengan desain yang sederhana, pengujian dilakukan di setiap tahap pengembangan, dan dokumentasi perangkat lunak yang cukup. Extreme programming $(X P)$ cocok untuk tim kecil hingga menengah dan menitik-beratkankan pada komunikasi yang dalam, pengerjaan dilakukan secara incremental dan interaktif untuk menghadapi kebutuhan yang berubah dengan cepat [9].

Ada lima cara penting dalam Extreme Programming $(X P)$ untuk meningkatkan proyek perangkat lunak yaitu communication, simplicity, feedback, respect, dan courage. Programmersenantiasa berhubungan dengan klien dan programmer lainnya dalam tim. Desain dibuat sesederhana mungkin. Umpan balik dilakukan mulai dari hari pertama dengan terus menguji perangkat lunak. Sistem atau perangkat lunak yang berfungsi diserahkan secepatmungkin kepada klien dan menanggapi perubahan yang diinginkan klien bahkan di akhir siklus. Metode Extreme programming $(X P)$ seperti yang ditunjukkan pada Gbr. 1, terdiri dari 4 tahapan yaitu planing, design, coding dan testing[9].

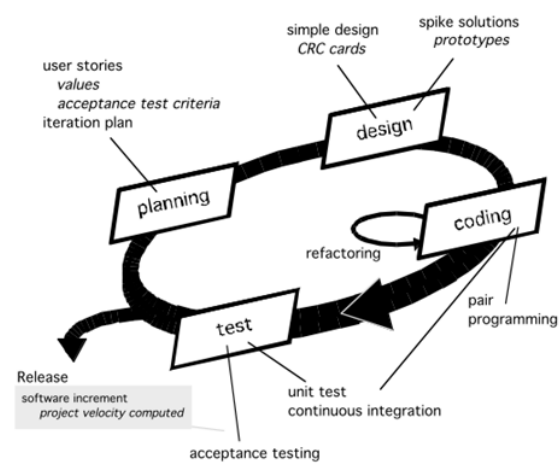

Gbr. 1 Tahapan model Extreme Programming(XP)

\section{METODE PENELITIAN}

Pengumpulan data dilakukandengan teknik wawancara dan observasi untuk mengidentifikasi masalah dan mengetahui proses persediaan barang yang terjadi perusahan.Dalam penelitian ini juga dilakukan studi literatur dengan mempelajari literaturliteratur yang berhubungan dengan topik penelitian, yaitu mengenai perancangan sistem informasi persediaan barang, Extreme Programming $(X P)$ dan literatur-literatur lain yang mendukung penelitian. Model pengembangan sistem yang digunakan adalah Extreme programming $(X P)$ yang terdiri dari 4 tahapan, yaituplanning, design, coding dan testing. 
1) Planning

Pada tahap ini pengembang melakukan identifikasi dan analisis kebutuhan bisnis, kebutuhan pengguna, dan kebutuhan sistem. Pada tahap ini juga akan dibuat user storiesdari setiap kebutuhan. User storiesberfungsi sebagai dasar pembangunan sistem.

2) Design

Tahapan desain merupakan tahapan dimana dilakukan perancangan alur kerja, basis data dari sistem yang akan dibangun berdasarkan user stories pada tahap planning.

3) Coding

Tahap ini adalah tahapan implementasi atau pembuatan kode program sesuai dengan rancangan sistem dan basis data yang dibuat pada tahap sebelumnya. Tahap ini boleh dilakukan secara iteratif (code refactoring) jika terdapat perubahan.

4) Testing

Tahapan ini merupakan tahapan pengujian perangkat lunak/sistem. Pengujian dilakukan pada setiap modul yang sedang bangun untuk memastikan sistem yang dikembangkan sesuai dengan permintaan dan kebutuhan pengguna/klien. Apabila modul yang dikembangkan masih belum sesuai, maka akan dilakukan perbaikan. Perbaikan dilakukan sampai modul yang dikembangkan sesuai dengan permintaan pelanggan.

\section{HASIL DAN PEMBAHASAN}

Hasil penelitian ini adalah rancangan sistem informasi persediaan barang pada Perusahaan Karya Cipta Buana Sentosa dengan metode pengembangan perangkat lunak Extreme Programming yang terdiri dari beberapa tahapan yaitu planning, design, coding, testing. Perancangan perangkat lunak menggunakan Unified Modeling Language (UML).

\section{A. Planning}

Pada tahap ini akan dilakukan analisis kebutuhan bisnis, kebutuhan penggunaan kebutuhan sistem. User storiesakan dibuat berdasarkan kebutuhan pelanggan. User storiesberfungsi sebagai dasar pembangunan sistem. Berikut adalah user storiesyang telah dibuat.

TABEL 1

USER STORIES

\begin{tabular}{|c|c|}
\hline Pengguna/user & Kebutuhan Sistem \\
\hline Admin & $\begin{array}{l}\text { Adminmerupakan pengguna } \\
\text { dengan otoritas akses terbatas } \\
\text { halaman administrator. Admin } \\
\text { dapat mengelola data } \\
\text { pengguna dan menentukan } \\
\text { hak akses, mengelola data } \\
\text { master dan mengubah } \\
\text { password. }\end{array}$ \\
\hline Staf gudang & $\begin{array}{l}\text { Staf gudang adalah pengguna } \\
\text { dengan otoritas akses terbatas } \\
\text { pada halaman gudang. Staf }\end{array}$ \\
\hline
\end{tabular}

\begin{tabular}{|c|c|}
\hline & 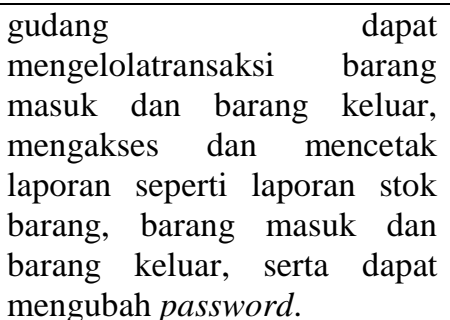 \\
\hline Manajer & $\begin{array}{l}\text { Manajer adalah pengguna } \\
\text { dengan otoritas akses terbatas } \\
\text { pada halaman manajer. } \\
\text { Manajer dapat mengakses dan } \\
\text { mencetak laporan seperti } \\
\text { laporan stok barang, barang } \\
\text { masuk dan barang keluar, } \\
\text { serta dapat mengubah } \\
\text { password. }\end{array}$ \\
\hline
\end{tabular}

TABEL 2

KEBUTUHAN BISNIS

\begin{tabular}{|l|l|}
\hline Perangkat Keras & \multicolumn{1}{|c|}{ Perangkat Lunak } \\
\hline PC / Laptop & Web Server / Apache \\
Printer & (Xampp) \\
& MySQL \\
& Adobe Dreamweaver CS4 \\
& Google Chrome \\
& Ms. Office \\
\hline
\end{tabular}

B. Design

Pada tahapan ini dibuat rancangan sistem yaitu use case, activity diagramdan class diagram.

1) Use case

Use casemenggambarkan apa saja yang dapat dilakukan aktor pada sistem informasi persediaan barang. Berdasarkan analisis kebutuhan pada tahap planning, terdapat tiga aktor pada sistem informasi ini yaitu admin, staf gudang, dan manajer. Masing- masing aktor memiliki akses yang berbeda. Berikut adalah use case dari ketiga aktor.

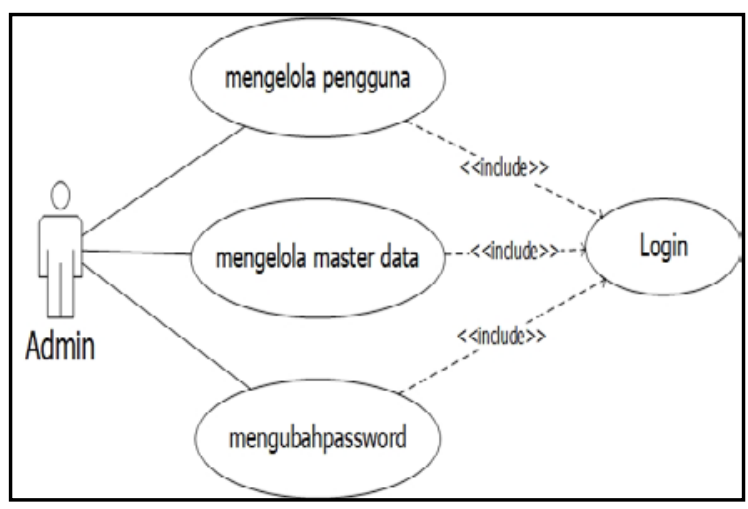

Gbr 2. Use CaseAdmin 


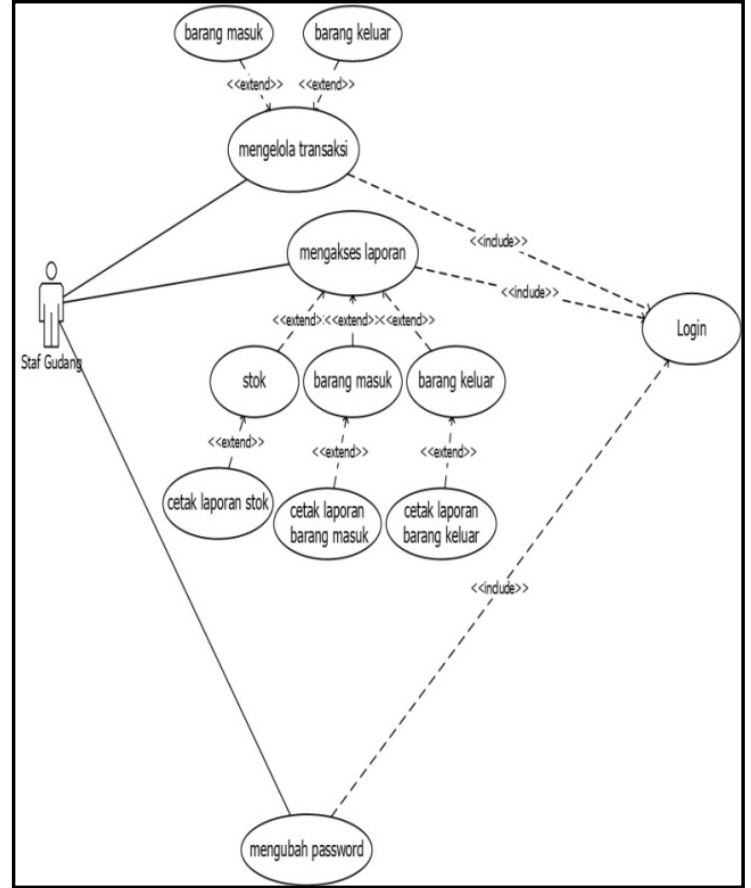

Gbr. 3Use Case Staf Gudang

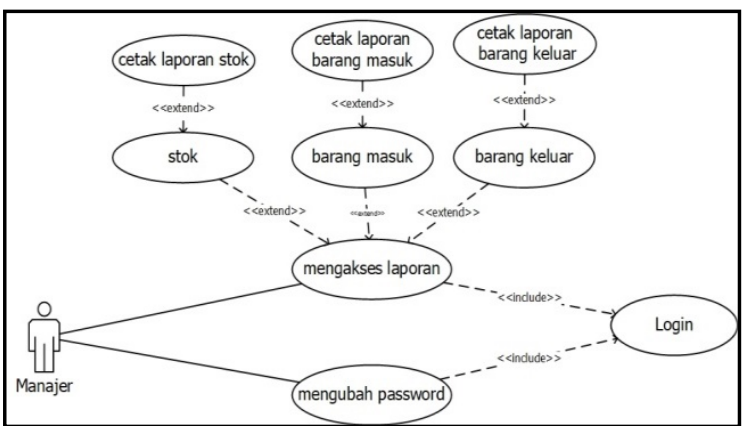

Gbr. 4Use Case Manajer

2) Activity Diagram

Activity diagrammenampilkan bisnis proses dan alur aktivitas dalam sebuah sistem yang akan dibangun[10].Activity diagramdibuat untuk menjelaskan aktivitas aktor dan komputer dalam sistem. Admin, staf gudang manajer harus melakukan login terlebih dahulu dengan username dan password yang telah dibuat. Sistem akan melakukan validasi username dan password yang dimasukkan. Apabila username dan password yang dimasukkan validpengguna langsung diarahkan ke halaman utama sistem, namun apabilausername dan passwordtidak valid akan kembali kehalaman login. Berikut adalah activity diagramdari sistem informasi persediaan barang pada perusahaan Karya Cipta Buana Sentosa.

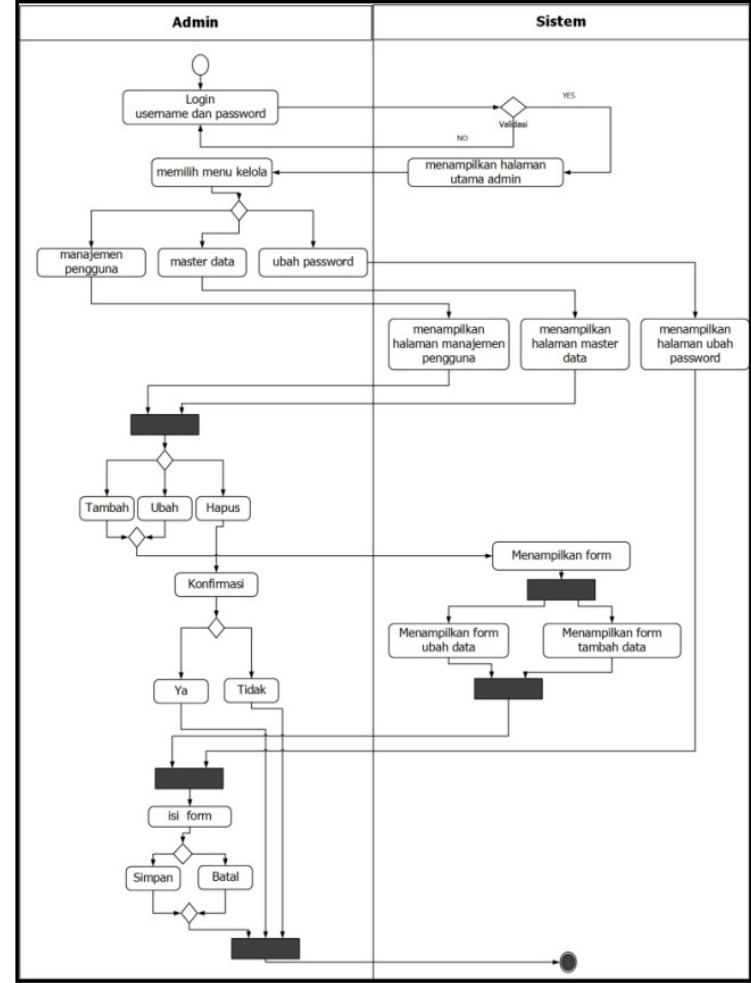

Gbr. 5Activity Diagram Admin

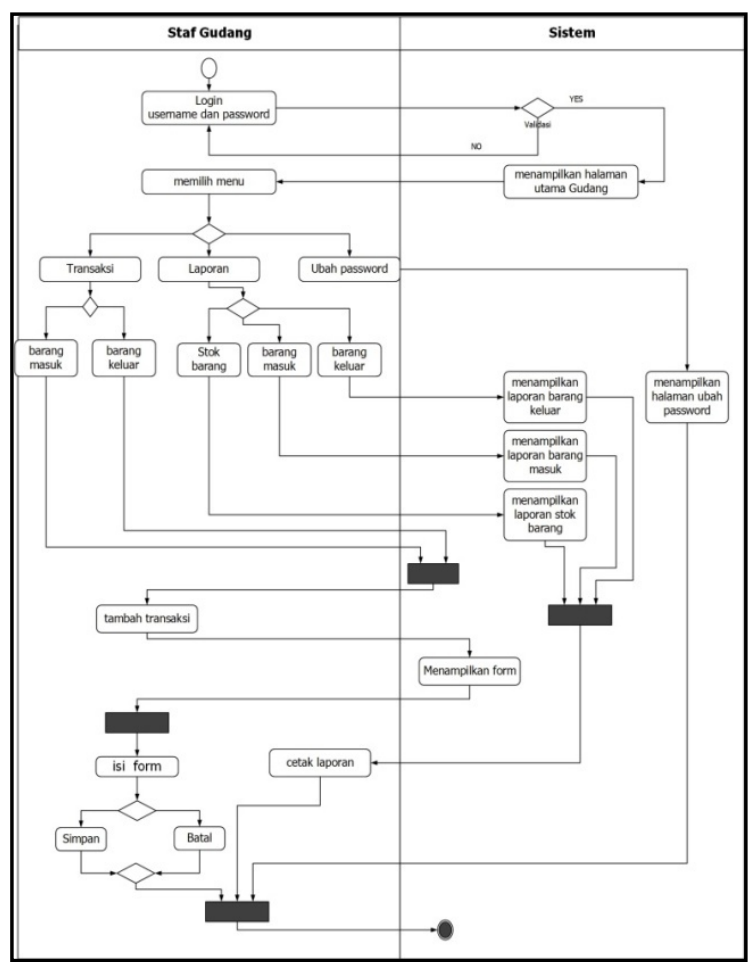

Gbr. 6Activity Diagram Staf gudang 


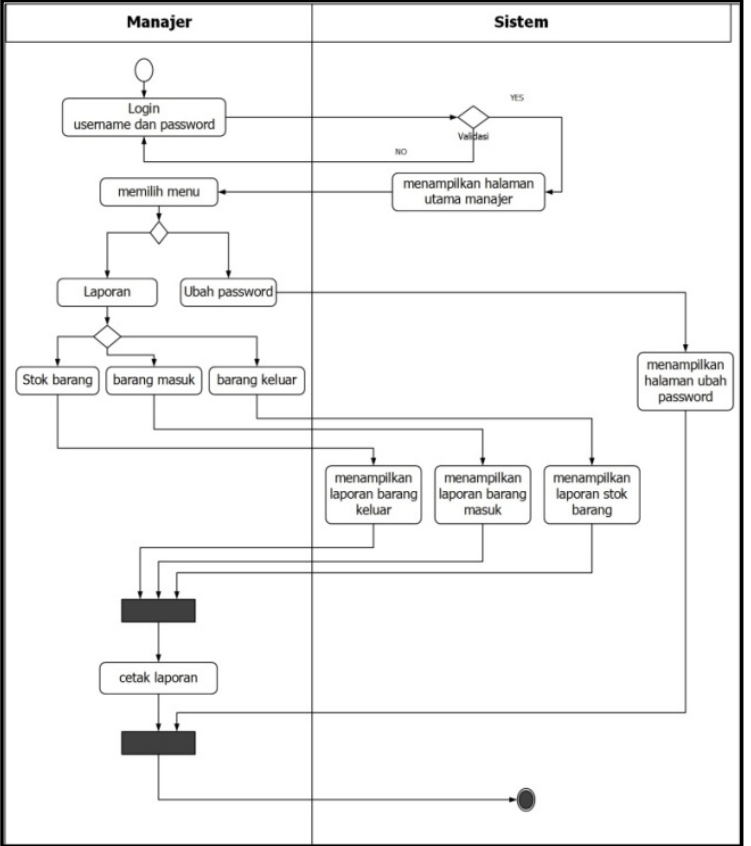

Gbr. 7Activity Diagram Manajer

3) Class Diagram

Class diagram menggambarkan struktur dari sebuah sistem dengan mendefinisikan kelaskelas, atribut dan hubungan antar kelas yang akan dibuat untuk membangun sistem[11].

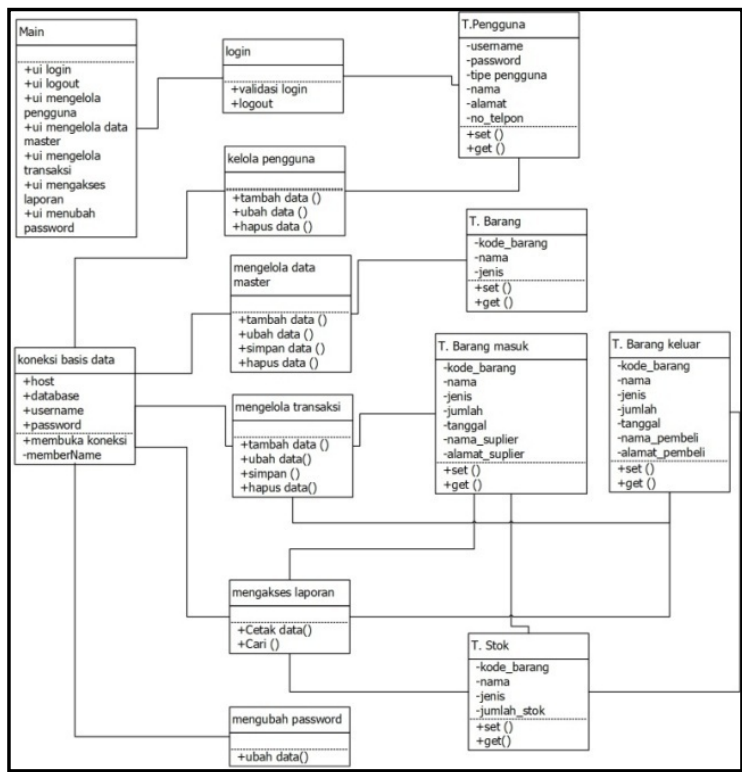

Gbr. 8Class Diagram

\section{Coding}

Tahapan ini adalah tahapan implementasi atau pembuatan kode program sesuai dengan rancangan sistem dan basis data yang telah dibuat. Penulisan coding (pengkodean) menggunakan bahasa pemrograman PHP dan My SQL sebagai databasenya. Dalam Extreme Programming (XP) proses penulisan program atau pengkodean dilakukan secara berpasangan [12]

\section{Testing}

Testing atau pengujian merupakan elemen kunci dari Extreme Programming (XP)[13]. Pengujian dilakukan pada setiap modul yaitu modul admin, staf gudang dan manajer untuk memastikan sistem yang dikembangkan sesuai dengan permintaan dan kebutuhan pengguna/klien. Apabila masih terdapat perubahan yang diinginkan pelanggan maka akan dilakukan perbaikan.

\section{PENUTUP}

Kesimpulan dalam penelitian ini berdasarkan analisis dan pembahasan yang telah dilakukan adalah sebagai berikut:

- Perancangan sistem informasi persediaan barang ini menggunakan pendekatan Agile Software Developmentdengan model Extreme Programming $(X P)$ membuat pembuatan sistem menjadi lebih cepat dan sesuai dengan kebutuhan klien.

- Sistem informasi persediaan barang ini dapat mempermudah perusahaan dalam mengelola data persediaan barang sehingga menjadi lebih efektif dan efisien

- Pencarian informasi persediaan/stok dan laporan menjadi lebih akurat, cepat, dapat dengan mudah diakses dan dicetak kapan pun dibutuhkan

- Sistem yang dirancang menggunakan tiga hak akses yang diberikan kepada Admin, Staf Gudang, dan manajer sehingga data persediaan barang bisa terorganisir dan terpantau dengan baik.

\section{REFERENSI}

[1] M. O. Riku and D. B. Setyohadi, "Strategic plan with enterprise architecture planning for applying information system at PT. Bestonindo Central Lestari,” in 2017 5th International Conference on Cyber and IT Service Management, CITSM 2017, 2017.

[2] A. O. Sari and E. Nuari, "Rancang Bangun Sistem Informasi Persediaan Barang Berbasis Web Dengan Metode Fast (Framework For The Applications),” J. PILAR Nusa Mandiri, vol. 13, no. 2, pp. 261-266, 2017.

[3] O. Pahlevi, A. Mulyani, and M. Khoir, "SISTEM INFORMASI INVENTORI BARANG MENGGUNAKAN METODE OBJECT ORIENTED DI PT . LIVAZA TEKNOLOGI INDONESIA JAKARTA,” vol. 5, no. 1, 2018.

[4] N. W. Purnawati and D. B. Setyohadi, "The Analysis of Implementation Business Model Canvas At The EMarketplace Dipeta Company,” vol. 4, no. 2, pp. 125-133, 2017.

[5] Y. I. Chandra, "PERANCANGAN APLIKASI RESEP MAKANAN TRADISIONAL INDONESIA MENGGUNAKAN PENDEKATAN AGILE PROCESS DENGAN MODEL EXTREME PROGRAMMING BERBASIS ANDROID,” pp. 28-29, 2016.

[6] R. Rahmi, R. P. Sari, and R. Suhatman, "Pendekatan Metodologi Extreme Programming pada Aplikasi ECommerce ( Studi kasus Sistem Informasi Penjualan Alatalat Telekomunikasi ),” vol. 2, no. 2, pp. 83-92, 2016. 
[7] J. Pries-Heje and R. Baskerville, "The translation and adaptation of agile methods: a discourse of fragmentation and articulation,” Inf. Technol. People, vol. 30, no. 2, pp. 396423, 2017.

[8] P. Serrador and J. K. Pinto, "Does Agile work? - A quantitative analysis of agile project success,” Int. J. Proj. Manag., vol. 33, no. 5, pp. 1040-1051, 2015.

[9] R. V. Anand and M. Dinakaran, "Popular Agile Methods in Software Development: Review and Analysis,” Int. J. Appl. Eng. Res. ISSN, vol. 11, no. 5, pp. 973-4562, 2016.

[10] D. Krisbiantoro, M. Imron, A. D. Riyanto, T. R. Dewi, S. Informasi, and S. A. Purwokerto, "Implementasi XP Programming Terhadap Sistem Informasi Pelayanan Publik Administrasi Desa Berbasis Web,” pp. 308-317.
[11] I. Safi, S. Suryono, and W. Ciptaningrum, "RANCANGAN APLIKASI LAYANAN PENGADUAN MASYARAKAT DENGAN METODE EXTREME PROGRAMMING ( Studi kasus : Kabupaten Ngawi ),” no. 32, pp. 7-12, 2017.

[12] P. Sikap et al., "Perancangan Prototipe Sistem Pemesanan Makanan dan Minuman Menggunakan Mobile Device," Indonesia Jurnal on Networking and Security, vol. 1, no. 2. pp. 1-10, 2015.

[13] H. Zanzabil, M. Zainuddin, and I. Pradesan, "RANCANG BANGUN SISTEM INFORMASI LAYANAN KESEHATAN MASYARAKAT BERBASIS MOBILE PADA RSUP Dr. MOHD. HOESIN DAN PALANG MERAH INDONESIA,” no. x, pp. 1-9, 1978. 